\title{
DOI: 10.7596/taksad.v5i4.615
}

\section{The Evolution of Academic Libraries in the Age of Technology}

\author{
Yasaman Saharkhiz*1 \\ Majid Valizadeh ${ }^{2}$ \\ Hengameh Salamat ${ }^{3}$
}

\begin{abstract}
In the present age, one of the main elements in every country is information and its role in the development of countries. In such an era, universities are pioneers in development and knowledge production in which, academic libraries also play a significant role. In the design field, libraries that have long been synonymous with peace and tranquility are now considered as a place in which there should be a balance between quiet atmosphere and social dynamic mood. The aim of this study is to examine the evolution of spaces of academic libraries, which is constantly being changed as a result of technological advancements and alteration of old systems with new ones. Our research method includes reviewing similar domestic samples, conforming examples to library standards and examining the changing process of several foreign libraries over a period of time. The results of this study indicate that generally, modern libraries have fewer spaces for paper books and publications and individual study, instead, more spaces are dedicated to places for group studies and using computer. This change has influenced the function of the spaces, the relation between different parts of the library and people who use it.
\end{abstract}

Keywords: Library, University, Technology, Space performance, Modern systems.

\footnotetext{
$1 *$ Corresponding Author, Department of Architecture, Engineering Faculty, Islamic Azad University-North Tehran Branch, Tehran, Iran.

${ }^{2}$ Department of Civil Engineering, Tech \& Engineering Faculty, Islamic Azad University, Sanandaj Branch, Sanandaj, Iran.

${ }^{3}$ Department of Civil Engineering, Tech \& Engineering Faculty, Bu-Ali Sina University, Hamedan, Iran.
} 


\section{Introduction}

In the traditional sense, a library is a collection of books which are kept in a place in order to be read by people. Advancements in information technology, quick and remote access to them lead to various forms of keeping and transforming information and even sometimes no space and building is required. However, libraries still retain their roles and even with the arrival of technology, presence of comprehensive libraries seems necessary.

According to issues mentioned above, it is necessary to express research hypotheses to answer questions.

Research hypotheses

$\checkmark$ The uses of new verbal and non-verbal systems have a great influence on using libraries.

$\checkmark$ Designing based on new needs is very effective at the level of service providence.

Research objectives

$\checkmark$ Increasing application domain of libraries and resources and performance improvement of services with regard to telecommunication

$\checkmark$ Investigating the conformity of libraries' required spaces to the new needs of users

Research process

Research process consists of two recognition and analysis steps. In the first step, primary recognition, domestic samples were reviewed, compared and evaluated based on existing standards. In the next step, analysis and intervention, goals and principles were developed, solutions were presented and evaluated and library spaces were organized.

\section{Library History}

In the past, there had been no difference between a library and a duplication room. Temples of Babylon and Assyria had been full of clay tablets. In Greece, the Byzantine Empire, and after the advent of Islam, in masques such as Al-Aqsa and Umayyad masques in Damascus monasteries and new established universities in Europe until the late medieval all had been centers for keeping books. In Iran, there is no detailed information about libraries before the advent of Islam and all libraries were destroyed by Arab invading. Marv library, Moqadasi library in Shiraz, Alamut and Sheikh Safi libraries in Ardebil and Astan Quds library are among oldest libraries in Iran. The first academic library was built in Tehran University and 
the most significant of academic libraries are Central Library and Documentation Centers of Tehran and Sharif universities (Masoodi Nejad, 2007).

In general, libraries are divided into 6 groups: 1. National, 2. Academic and Research, 3. Public, 4. Specialized, 5. Schools, and 6. Private (Golkar \& Rahimi, 2010).

\subsection{Academic and Research Libraries}

With the invention of printing, many copies of the lessons were distributed in different places and universities started establishing libraries. Except large central libraries, there are also some smaller collections in faculties. The main objective of a modern academic library is to participate, be active and implement the goals of higher education.

Once, academic universities were only repositories to store books and had a minor role. But now they are considered as an active force in teaching and research. One of the factors that help universities achieving a material and spiritual source to serve societies is libraries. Creation of distance learning and correspondence courses and the increasing importance of information have made the role of academic libraries more significant.

A library should be a dynamic tool for students learning and one of the components of an efficient library is having a consistent structure with universities' objectives. Elements such as users, library staffs and resources form the performance of a library (Golkar \& Rahimi, 2010).

\section{Different Types of Libraries from Technical Point View}

Technically, libraries are divided into three categories: 1. Paper libraries, 3. Automatic libraries, and 3. Electronic libraries.

Approaches of a library:

$\checkmark$ Qualitative

$\checkmark$ Quantitative

\subsection{Qualitative Approach}

Quality issues means determining the role of library and expanding a plan which allows the library to reach its goals. Research plans and facilities are included in libraries, but they are also a place for the person's presence, such human issues play an important role in the position of a library and designing them is challenging since it must be designed for staffs and 
users. While these two groups with their own characteristics and requirements are separate from each other, they must interact with one another. One of the major goals in designing a library is to successfully meet the needs that are sometimes in conflict (Golkar \& Rahimi, 2010).

Factors involved in the quality of the libraries:

$\checkmark$ The library area should be inviting, and it should have convenient accessibility, clarification of inner activities is another important quality of the library

$\checkmark$ Flexibility and the capability to adapt to future needs and changes in architecture

$\checkmark$ Being economical

$\checkmark$ Income generation of the complex

$\checkmark$ Respecting the existing culture and values

$\checkmark$ Improving existing qualities

\subsubsection{Concept and Indexes of Quality in Academic Libraries:}

According to Van House et. al (1990) indexes that measure quality and performance of academic and research libraries can be divided into four groups:

1. Overall satisfaction of users

2. Available resources and using them

3. Facilities and function of the library

4. Information services

Also, Calvert and Hernan (1997, quoted from Praditteera) assume the following indexes in a research about quality from students and faculty members' points of views that were from two New Zealand universities:

1. Guidance

2. Waiting time

3. Electronic services

4. Library staff

5. Resources order

6. Building and environment

7. Furniture and facilities

8. Minor educational resources (Babalhavaeji et al., 2009) 


\subsection{Quantitative Approach}

Quantification issues of library designing include: place of functional spaces, type and amount of space, location of facilities, various lightings and other electrical and mechanical backups that a library requires (Golkar \& Rahimi, 2010).

Comparison of famous Iranian academic libraries with existing standards:

Due to the great number of fields of study, students and the huge amount of information required for meeting existing needs, academic libraries are evaluated based on the standards of Higher Education Libraries (ACRL).

According to the standard 4 of Iranian academic libraries (Hoseini \& Koohi Rostami, 2010) we have:

$\mathrm{V}=$ basic collection $+100 \mathrm{~F}+12 \mathrm{E}+335 \mathrm{U}+3000 \mathrm{M}+20000 \mathrm{D}$

In this equation:

$\mathrm{F}=$ Number of full-time faculty members

$E=$ Number of all full-time students

$\mathrm{U}=$ Number of undergraduate fields

$\mathrm{M}=$ Number of Master's fields

$\mathrm{D}=$ Number of PhD fields

$\mathrm{V}=$ Total number of required Collection for the library

In the following part we have reviewed five Iranian academic libraries as samples and compared their collections with existing standards (Hoseini \& Koohi Rostami, 2010):

Table 1. Library collections of five Iranian academic libraries

\begin{tabular}{|c|c|c|c|c|c|c|c|c|c|}
\hline \multirow{2}{*}{ University } & \multicolumn{2}{|c|}{ Book } & Total & \multicolumn{2}{c|}{ Periodical } & Total & Thesis & $\begin{array}{c}\text { Non- } \\
\text { Books }\end{array}$ & $\begin{array}{c}\text { Total } \\
\text { collection }\end{array}$ \\
\hline & Persian & Latin & & Persian & Latin & & \multicolumn{4}{|c|}{} \\
\hline Tehran & 280000 & 120000 & 400000 & 4600 & 3615 & 8215 & 36000 & & 444215 \\
\hline
\end{tabular}




\begin{tabular}{|c|r|r|r|r|r|r|r|r|r|}
\hline $\begin{array}{c}\text { Shahid } \\
\text { Beheshti }\end{array}$ & 220000 & 135430 & 355430 & 1620 & 3193 & 4813 & 5100 & 30000 & 395343 \\
\hline Tabriz & 67245 & 65000 & 132245 & 1695 & 445 & 2140 & 4000 & 1615 & 140000 \\
\hline Shiraz & 42325 & 63320 & 105645 & 1906 & 1288 & 3194 & 1753 & 514 & 111106 \\
\hline Mashhad & 60000 & 35000 & 95000 & 75 & 180 & 255 & 2400 & 15000 & 112655 \\
\hline
\end{tabular}

Table 2. Per capita of resources in five Iranian academic libraries

\begin{tabular}{|c|c|c|}
\hline University & Per capita book & Per capita publication \\
\hline Tehran & 12.5 & 0.2 \\
\hline Shahid Beheshti & 33 & 0.4 \\
\hline Tabriz & 12 & 0.2 \\
\hline Shiraz & 11 & 0.3 \\
\hline Mashhad & 4.5 & 0.01 \\
\hline
\end{tabular}

According to obtained results, we observed that all five libraries have a collection under desirable limit. For example, based on the academic standard, book collection of the Tehran University library must be 4404000 while statics show that it is $75 \%$ lower than standard limit.

\subsubsection{Evaluation of Library Spaces}

Space is one of the main elements in a library and it can play a decisive role in the success or failure of plans. There is a direct relationship between suitable spaces of a library and using its services and study and research in a comfortable, calm, pleasant, attractive and accessible place, which are necessities of such a cultural and spiritual place, entail many fruitful results (Haghighi, 2009). 
Required space of libraries is measured based on standard 6 (ACRL) in which the following elements are included: number of students, number of staffs, their required space and the number of journals available in the collection, to the outcome of this measurement, other elements such as required spaces for deploying non-copy and microform material and services related to them, bibliographic instructions for groups, required spaces for facilities and different types of services of library technology must be added.

According to statics, the condition of both Tehran University and Shahid Beheshti University, which have been used as model samples in the present study, is as follow:

Table 3. The condition of Tehran University and Shahid Beheshti University

\begin{tabular}{|c|c|c|c|c|}
\hline University & $\begin{array}{c}\text { Number of } \\
\text { students }\end{array}$ & Total collection & $\begin{array}{c}\text { Number of } \\
\text { staffs }\end{array}$ & $\begin{array}{c}\text { Number of } \\
\text { available study } \\
\text { seats }\end{array}$ \\
\hline Tehran & 21627 & 1035564 & 227 & 3528 \\
\hline Shahid & & & & \\
\hline Beheshti & 12578 & 216073 & 59 & 883 \\
\hline
\end{tabular}

Comparison of required spaces with available spaces based on C Formula is presented in the table below:

Table 4. The condition of Tehran University and Shahid Beheshti University

\begin{tabular}{|c|r|r|r|r|}
\hline University & $\begin{array}{c}\text { Total required } \\
\text { spaces }\end{array}$ & $\begin{array}{l}\text { Available } \\
\text { spaces for } \\
\text { study }\end{array}$ & $\begin{array}{l}\text { Available } \\
\text { spaces for } \\
\text { collection }\end{array}$ & $\begin{array}{c}\text { Available } \\
\text { spaces for } \\
\text { staffs }\end{array}$ \\
\hline Tehran & 31735 & 7901 & 10201 & 2231 \\
\hline Shahid & 10145 & 7011 & 2007 & 1127 \\
\hline
\end{tabular}




\section{Some Ideas on Future Academic Libraries}

In collaboration between New Jersey ACRL (Association of College and Research Libraries) and the library of Fairleigh Dickinson, and essay contest was held on a new thought about a future with the theme of "scientific library in 2012." Analysis after the contest showed that among three following issues one is considered as more important than others.

- Technology development

- Role of library

- Role of librarians

The prevailing view in literature is that technology is the factor that determines changes in academic libraries.

\subsection{Technological Changes'Views}

Two top papers predicted that in 2012, academic libraries would widely use various media. Silverstone, from Los Angeles Guru Media, predicted libraries with visual infrastructure such as projectors, virtual display spaces, learning cafeterias and subject-based scattered structures using multimedia libraries and other knowledge-based packages, exhibitions and laboratories. From Place to Task, which is an article, shows that a day is a range of services provide for packaging electronic tools and created resources by librarians.

Using video clips and various media makes the complicated process of information collection easy for the learner. Access to pre-written materials, software, lists and websites.

\subsection{Architects' views on current designs of libraries}

Printed collections will be the primary function of libraries in the future. Flexibility in classification, closeness and compactness of shelves, printed and electronic media all will be ordinary issues. Building a space and place (architectural) requires financial and cultural compliance with social values. If we are unable to comply with standards, then how can we judge the quality of what we have built?

Academic libraries will also continue using printed materials and projects would add the most possible space. In some parts we have workstations that are $135 \mathrm{~cm}$ wide and their aim is to help students and professionals at any given moment.

Service stations have designed at the entrance of libraries such as reference desks, exchanged 
books between libraries and media services and there are also OPAC terminals.

So technology does not reduce space requirements. Availability of electronic information provides a variety of required spaces and we can visit libraries electronically or in person.

Nowadays, developed facilities and service stations for exchanges between libraries, group study, holding national seminars and regular meetings of different academic groups provides an opportunity for academicians to acquire knowledge and spread it.

The changes are that we are noticing a movement toward breaking the barriers of a wide range of listeners' learning and informal learning with various forms in calmer atmospheres. Even in academic libraries there is a trend toward offering more informal areas and people can drink coffee, connect to the internet or smoke.

Future of libraries is unpredictable to the extent that there would be the possibility for a building to be a flexible place. But results are not clear and complete flexibility is an expensive option. People expect to sit wherever they desire, but if someone assumes a place only for study, then he would probably think about the arrangement of tables by the window. Therefore, it is necessary to pay enough attention when addressing flexibility. The library is a building and an aspect which reflects the history of a society. Through successful management, we must strive to match spaces, light, materials, details and flexibility with human spirit.

\section{Technology in Libraries}

In the late 1970s and 1980s computer was considered as the basis for creating joined Computer Library Center (OCLC), one of the systems for borrowing books and in fact, the first system dedicated to the library. There have been two periods for libraries in the age of computers:

First is automatization of libraries during which the use of computer, library processes such as borrowing, cataloging, control, periodicals, continuous search etc. were made more efficient.

Second is digitization of libraries during which some contents of libraries were digitized and stored and were accessible through computer systems (Bachland, M, 2000).

In future, libraries should move beyond their internal environment. They should consider the trends of information technology market, political, social and legal trends and also changes in methods of information collection and their use since the waves of changes leads to more 
changes that are constantly increasing.

With this trend of updating libraries, gradually many people will work in the field of information. Current situation of libraries will change in the future and they will allow users to search and obtain their needed information from outside the library such as their homes.

\section{Discussion and conclusion}

Table 5. Obtained results from the studied samples

\begin{tabular}{|c|c|c|c|c|c|c|c|c|}
\hline & $\begin{array}{c}\text { Countr } \\
\mathrm{y}\end{array}$ & $\begin{array}{l}\text { Year } \\
\text { of } \\
\text { creati } \\
\text { on }\end{array}$ & Area & $\begin{array}{c}\text { Capacit } \\
\text { y for } \\
\text { people }\end{array}$ & $\begin{array}{l}\text { Numbe } \\
\text { r of } \\
\text { books }\end{array}$ & $\begin{array}{l}\text { Numb } \\
\text { er of } \\
\text { floors }\end{array}$ & $\begin{array}{l}\text { Numbe } \\
\text { r of } \\
\text { study } \\
\text { spaces }\end{array}$ & $\begin{array}{c}\text { Number } \\
\text { of } \\
\text { computers }\end{array}$ \\
\hline Alexandrina & Egypt & 2002 & $\begin{array}{r}80,00 \\
0\end{array}$ & 2,000 & $\begin{array}{r}4,000,00 \\
0\end{array}$ & 10 & & \\
\hline Seattle public & USA & 2004 & $\begin{array}{r}33,00 \\
0\end{array}$ & & $\begin{array}{r}780,00 \\
0\end{array}$ & & & \\
\hline $\begin{array}{c}\text { Library for the } \\
\text { faculty of } \\
\text { philology }\end{array}$ & $\begin{array}{c}\text { German } \\
\mathrm{y}\end{array}$ & 2005 & $\begin{array}{r}20,72 \\
6\end{array}$ & 39,000 & $\begin{array}{r}700,00 \\
0\end{array}$ & 5 & 650 & \\
\hline $\begin{array}{c}\text { Library of } \\
\text { Brandenburg } \\
\text { Technology } \\
\text { University }\end{array}$ & $\begin{array}{c}\text { German } \\
\mathrm{y}\end{array}$ & 2005 & 7,630 & 6,400 & & 6 & & \\
\hline Stirling library & U.K & 2008 & & & & 3 & 240 & 100 \\
\hline St Aubyn library & U.K & 2011 & 650 & & & 2 & 29 & 14 \\
\hline Sighthill LRC & $\begin{array}{c}\text { Scotlan } \\
\mathrm{d}\end{array}$ & 2010 & 2,520 & 16,000 & 60,000 & 5 & 650 & 350 \\
\hline Aston University & U.K & 2011 & 7,038 & 1,000 & & 4 & 496 & 160 \\
\hline
\end{tabular}


Based on studies and reviews it can be concluded that libraries which are designed for present and future must move toward more informal and flexible spaces, they should reflect technology or more specifically computer technology and with the passage of time they must proceed toward a group, social and communal spaces, and the use of computer services. After studying and reviewing similar samples and the trend of space changes in modern libraries, it can be observed that as time passes on, modern libraries get to have more communal spaces and are designed to be more flexible, also the amount of electronic equipment and usage of computer services increase. Obtained results from the studied samples can be observed in the following table. It can be understood that in the process of designing new libraries, the number of paper books have been reduced and communal reading spaces and computer use have increased.

According to performed studies, the following table is presented for classification of results and suggesting new approaches in designing academic libraries:

Table 6. Classification of results and suggesting new approaches

\begin{tabular}{|c|c|c|c|}
\hline $\begin{array}{l}\text { Future outlook of } \\
\text { academic libraries }\end{array}$ & Current situation & Favorable situation & $\begin{array}{c}\text { Tools for } \\
\text { strengthening the } \\
\text { situation }\end{array}$ \\
\hline $\begin{array}{l}\text { Availability of } \\
\text { information }\end{array}$ & $\begin{array}{l}\text { Abstract of articles, } \\
\mathrm{CD} \text { and enclosures } \\
\text { and borrowing } \\
\text { books from library }\end{array}$ & $\begin{array}{l}\text { Printed collection } \\
\text { with online database } \\
\text { and broad electronic } \\
\text { resources }\end{array}$ & $\begin{array}{l}\text { User identification } \\
\text { through the } \\
\text { computer (image } \\
\text { search) and through } \\
\text { communication with } \\
\text { other libraries, it } \\
\text { provides services to } \\
\text { clients }\end{array}$ \\
\hline $\begin{array}{l}\text { Access to } \\
\text { information }\end{array}$ & $\begin{array}{l}\text { Moving toward } \\
\text { electronic books }\end{array}$ & $\begin{array}{c}\text { Remote access, } \\
\text { wireless }\end{array}$ & $\begin{array}{l}\text { Collections that are } \\
\text { not published } \\
\text { anymore and access } \\
\text { through linked } \\
\text { networks_creating }\end{array}$ \\
\hline
\end{tabular}




\begin{tabular}{|c|c|c|c|}
\hline & & & $\begin{array}{l}\text { international } \\
\text { archives (service } \\
\text { points for } \\
\text { transactions between } \\
\text { libraries) }\end{array}$ \\
\hline Study spaces & Quiet spaces & Group study spaces & $\begin{array}{l}\text { Complying work } \\
\text { spaces with study } \\
\text { spaces_creating } \\
\text { multimedia boards } \\
\text { makes it possible to } \\
\text { hold conferences } \\
\text { researchers or } \\
\text { specialists anywhere } \\
\text { in the world }\end{array}$ \\
\hline Computer access & $\begin{array}{l}\text { Local access of } \\
\text { online users }\end{array}$ & $\begin{array}{l}\text { Regional } \\
\text { information, public }\end{array}$ & $\begin{array}{l}\text { Wireless and laser } \\
\text { access to laptops and } \\
\text { personal software } \\
\text { must be private }\end{array}$ \\
\hline Orientation & $\begin{array}{l}\text { Hierarchical } \\
\text { performance }\end{array}$ & $\begin{array}{l}\text { Service- oriented } \\
\text { team }\end{array}$ & $\begin{array}{l}\text { Automatic } \\
\text { translators would } \\
\text { facilitate access } \\
\text { programs to inform } \\
\text { internationally }\end{array}$ \\
\hline Book reservoirs & $\begin{array}{l}\text { Extensive } \\
\text { availability of close } \\
\text { and open reservoirs } \\
\text { in libraries }\end{array}$ & $\begin{array}{l}\text { Reduction in the } \\
\text { number of printed } \\
\text { books and the size of } \\
\text { reservoirs_ } \\
\text { simultaneous use of } \\
\text { a single source for } \\
\text { multiple users }\end{array}$ & $\begin{array}{l}\text { Creating e-books, } \\
\text { using information } \\
\text { online and also using } \\
\text { compacted reservoir } \\
\text { systems (or } \\
\text { automatic storage } \\
\text { and retrieval system) }\end{array}$ \\
\hline
\end{tabular}




\begin{tabular}{|c|c|c|c|}
\hline Flexibility & $\begin{array}{l}\text { Defined limits in the } \\
\text { plan }\end{array}$ & $\begin{array}{l}\text { Creating flexibility } \\
\text { and space fluidity }\end{array}$ & $\begin{array}{l}\text { Use of dynamic } \\
\text { spaces, open spaces } \\
\text { for learning, } \\
\text { removing the } \\
\text { boundaries between } \\
\text { related spaces }\end{array}$ \\
\hline Using the library & $\begin{array}{l}\text { In traditional and } \\
\text { modern libraries, } \\
\text { spaces and printed } \\
\text { books are of more } \\
\text { importance_a place } \\
\text { to work separated } \\
\text { from a place to live }\end{array}$ & $\begin{array}{l}\text { Moving with the age } \\
\text { of technology, an } \\
\text { opportunity for } \\
\text { social interactions }\end{array}$ & $\begin{array}{l}\text { Moving toward } \\
\text { offering more } \\
\text { informal areas in } \\
\text { libraries where } \\
\text { people can drink } \\
\text { coffee, chat..., } \\
\text { creating free study } \\
\text { zones }\end{array}$ \\
\hline Role of librarians & $\begin{array}{l}\text { Presence of } \\
\text { librarians in a } \\
\text { special place to } \\
\text { provide services }\end{array}$ & $\begin{array}{l}\text { Highlighting the role } \\
\text { of librarians due to } \\
\text { technology advances }\end{array}$ & $\begin{array}{l}\text { Creating } \\
\text { workstations with an } \\
\text { area about 3.2- } 2.7 \\
\text { square meters for } \\
\text { momentary help to } \\
\text { people }\end{array}$ \\
\hline
\end{tabular}




\section{References}

Babalhavaeji, F. Isfandyari-Moghaddam, A. Aqili, SV. Shakooii, A. (2009). Quality Ussessment of Ucademic Library Performance. The Case of an Iranian Academic Library. Malaysian Journal of Library \& Information Science. 14 (2). 51-81.

Bachland, M, (2000). Future Libraries. Translated by Babak Partov. Ketabdar Publication. Tehran.

Haghighi, Mahmood, (2009). Evaluation of Tehran's Academic Libraries Spaces. Faculty Member of Psychology and Educational Sciences Faculty.

Hoseini, Seyyed Abedin, Koohi Rostami, Mansoor, (2010). Evaluation of Academic Libraries. Collections Based on the Standards of Iranian Academic Libraries.

Library Designing (2010). Principles of Architecture and Interior Design of Libraries from Classic to Modern. Translated and Compiled by Abtin. Elnaz Rahimi, Honar-e- Memari-eQarn Publication, Summer.

Masoodi Nejad, S, (2007). Designing the central library of Kashan. Master's Thesis. Shahid Beheshti University.

Praditteera, M. (2001). ISO 9000 Implementation in Thai Academic Libraries. PHD Dissertation. University of Pittsburgh.

Van House, N. Weil, B.T. and McClure, C.R. (1990). Measuring Academic Library Performance: A Practical Approach. Chicago: American library Association. 